\title{
Doctor Josef's Beauty (Ślicznotka doktora Josefa)
}

Author: Zyta Rudzka

First Published: 2006

Translation: German (Doktor Josefs Schönste, 2009).

About the Author: Zyta Rudzka (1964) is a playwright, novelist, and psychologist from Warsaw. She began her career as a poet in 1989 and debuted in 1991 with the novel White Clichés (Białe klisze) and became famous for her plays (e.g. The Sugar Bra, 2008, Cukier stanik) that were translated into Russian, Bulgarian, Italian and German and staged abroad (Kotkowska-Kachel, 2011).

Further Important Publication: Mykwa (1999, Mikveh; novel).

\section{Content and Interpretation}

The story focuses on two twin sisters, Leokadia and Czechna, who live together in a retirement home not far from Warsaw. The main storyline is short on action as it is based on descriptions of the lives and destinies of retirement home residents of Jewish origin, who are suffering an extraordinary hot summer. The atmosphere can be described as monotonous but somehow also familiar and laconic since most of the conversations are about the death which the elderly residents are about to face. ("And you wanna get buried or burnt?” Rudzka, 2006, pp. 146, 152, 183). The subject of death is not only evoked several times by the pensioners, but also by the life-threatening heat, which gets more intense during the story. The narrator's voice comments on this as follows: "The elderly people were spoiling fast. They had cancer. Exanthemas. Abscesses. Boils. As if they had cellulite on their faces. Dribbling. Sweating. Puffing. Trembling. Whimpering." (p. 271) Additionally, the head of the retirement home is portrayed as unusually strict and lacking compassion or indulgence. He cuts off the water supply in order to save water, makes the residents stand in a row to get showered or arbitrarily sends people to the "House by the Sea" that nobody has ever seen and from which nobody ever has returned. This basic plot is constantly interwoven with flashbacks to World War II and the sisters' fate in the Auschwitz concentration camp. They survived only because they were test subjects for doctor Josef (Mengele)'s experiments on twins ( $\rightarrow$ At Home with the Hitlers. The Hitlers' Kitchen). "He is approaching her again. doctor Josef. Slim. Heavenly. Not present. [...] Laughing. Loudly. Vociferously. Like a boy. Laughing with his lips. The greedy ones. The sucking ones. [...] He wants her to stretch out. To lay her naked shoulders on the metal bar that is covered with the excrement of strangers.” (pp. 204-205) Not only the narrator focuses on the detailed description of bodies; Czechna herself also emphasises her beauty and the fact that she survived Auschwitz thanks to her looks, for which she was called

Ә Open Access. () 2021 Elisa-Maria Hiemer, published by De Gruyter. (cc) BY-NC-ND This work is licensed under a Creative Commons Attribution-NonCommercial-NoDerivatives 4.0 License. https://doi.org/10.1515/9783110671056-030 
"Miss Auschwitz" (p. 67). The pensioners seem to be deprived of dignity and vitality. They are eking out a miserable existence in the home, which turns out to be anything but a shelter. In contrast, the unusual attractiveness of Czechna is even more remarkable and, at the same time, displaces her. The storylines are clearly defined by the use of tenses. Whereas the story in the retirement home is written in the past tense, the flashbacks to the childhood in Auschwitz are reported in the present tense from the viewpoint of a witness. The composition and the role of the narrator seem significant for the whole novel. The scenes in the retirement home and the concentration camp are distinguished by the setting and time, but are similar in terms of motifs. While the scenes are constantly mixed up, they are primarily linked by their inhumanity and the vivid depiction of physicality and carnality. In combination with the cruelty portrayed, they evoke feelings of embarrassment and discomfort. Throughout the story, there are incidences of posttraumatic stress disorder, since Leokadia suffers from anorexia, while Czechna is haunted by nightmares and cannot deal with suddenly occurring scenes in daily life that remind her of her childhood. The smell of urine makes her paradoxically recall the good odour of the doctor in Auschwitz, which signifies a psychopathological attraction to her tormentor ("I never thought I would say that [...] but I am longing for the concentration camp,” p. 162).

\section{Main Topics and Problems}

Not only the comparison of daily life in a retirement home to life in Auschwitz led to very varied reactions among critics. The text oscillates between a sort of sexual attraction and childish trust, for example illustrated by the usage of doctor Josef instead of his full name, and in metaphors describing him as a magician. It remains unclear if the doctor is interested in the girl for more than scientific reasons but the sexual connotations in the book can be considered as taboo breaking: "Doctor Josef's enthusiasm has to be muted. Maybe he could just nest in her. With the scalpel. With the needle. With the syringe. With bacteria. Sinking into her.” (pp. 206-207)

The novel also raises the problem of lack of solidarity and empathy for the traumatised victims. This becomes obvious when Czechna is convinced she has recognised a medical assistant some years later at a train station, which gives her a nervous breakdown. Instead of trusting her suspicion, she gets labelled as a sick, hence untrustworthy person. Her sister Leokadia goes through moments of humiliation in her marriage where her husband forces her to put on the prisoner's uniform. People around her try to explain this away with his alcohol addiction. For these reasons, Doctor Josef's Beauty is also a story about double traumatisation: in public and in private, in youth and old age (Hiemer, 2014, p. 324). The novel is a thematic synthesis of the topics Rudzka most commonly addresses in her plays and other novels. She is fascinated with bodies, especially older ones, psychological issues, Jewish topics, and more generally - questions of dignity. Due to its controversial plot and presentation, the novel triggered manifold reactions. Whereas Polish critics pointed out the realistic depiction of older people's isolation ( $\rightarrow$ The Boarding House), German critics accused 
the author for the double setting and considered it to be a cynical comparison between the retirement home and a concentration camp. The questionable allegories are surely not easy to adjust to, but they help the narrator to convey the inhuman living conditions to the reader by provoking uncomfortable feelings. The narrator considers these feelings to be necessary to understand what the victims went through and still are going through. Daily life in the retirement home reminds readers of a panopticon of physical and mental decline in people who are living together but apart and forgotten. Applying this reading, the text can be understood as a critique of the failure to commemorate and respect victims of the Holocaust.

\section{Cited Works}

Hiemer, E.-M. (2014). Outrageous Taboo Breaking or Ingenious Narrative Strategy? About Zyta Rudzka's „Ślicznotka doktora Josefa“ and its perception in German and Polish reviews. In: R. Ibler, ed., Der Holocaust in den mitteleuropäischen Literaturen und Kulturen seit 1989. Stuttgart: ibidem, pp. 317-329. Kotkowska-Kachel, M. (2011). Zyta Rudzka. In: A. Szałagan. Polscy pisarzy literatury przetomu XX i XXXI wieku. Stownik biobibliograficzny. Warszawa: Instytut Badań Literackich PAN, pp. 219-222.

\section{Further References}

Hiemer, E.-M. (2012). Generationenkonflikt und Gedächtnistradierung. Die Aufarbeitung des Holocaust in der polnischen Erzählprosa des 21. Jahrhunderts. Stuttgart: ibidem. Karwowska, B. (2009). Ciało. Seksualność. Obozy zagłady. Kraków: Universitas. KowalskaLeder, J. (2009). Doświadczenie zagłady z perspektywy dziecka w polskiej literaturze dokumentu. Wrocław: Wydawnictwo Uniwersytetu Wrocławskiego. Łebkowska, A. (2008). Empatia. O literackich narracjach przełomu XX i XXI wieku. Kraków: Universitas. Orski, M. (2007). Dryfując w gorączce powietrza. Odra 47(1), pp. 114-115. Stolzmann, U. (2009). Miss Auschwitz, nackt, vor Doktor Mengele. Neue Zürcher Zeitung, 23.5. Available at: https://www.nzz.ch/miss_auschwitz_nackt_vor_doktor_mengele-1.2609722 [Accessed 15.07.2019]. Ubertowska, A. (2007). Świadectwo - trauma - głos. Literackie reprezentacje Holokaustu. Kraków: Universitas.

\section{$\mathrm{EMH}$}

